\begin{tabular}{|c|c|}
\hline ANGIES & Angles \\
\hline $\begin{array}{l}\text { NEW PERSPEETIUES } \\
\text { ANGLOPHONE WITRLD }\end{array}$ & New Perspectives on the Anglophone World \\
\hline & $\begin{array}{l}9 \mid 2019 \\
\text { Reinventing the Sea }\end{array}$ \\
\hline
\end{tabular}

\title{
Video introduction to issue 9
}

\section{Geetha Ganapathy-Doré and Ludmila Volná}

\section{(2) OpenEdition}

\section{Journals}

\section{Electronic version}

URL: https://journals.openedition.org/angles/777

DOI: 10.4000/angles.777

ISSN: 2274-2042

\section{Publisher}

Société des Anglicistes de l'Enseignement Supérieur

\section{Electronic reference}

Geetha Ganapathy-Doré and Ludmila Volná, "Video introduction to issue 9", Angles [Online], 9| 2019, Online since 01 November 2019, connection on 07 June 2022. URL: http://journals.openedition.org/ angles/777; DOI: https://doi.org/10.4000/angles.777

This text was automatically generated on 7 June 2022.

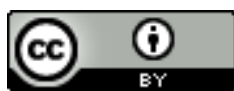

Angles est mise à disposition selon les termes de la Licence Creative Commons Attribution 4.0 International. 


\title{
Video introduction to issue 9
}

\author{
Geetha Ganapathy-Doré and Ludmila Volná
}

This media file cannot be displayed. Please refer to the online document http:// journals.openedition.org/angles/777

\section{Transcript:}

1 I am Geetha Ganapathy-Doré. I am the current president of the Society for Activities and Research on the Indian World (SARI). I am Ludmila Volná. I am currently one of Vice-Presidents of the Society for Activities and Research on the Indian World. Welcome to this special issue on "Reinventing the Sea".

2 Most of the papers collected in this issue were first presented at the SARI conference on Reinventing the Sea, Precarity, Epistemology and Narratives held in June 2017. We, as guest editors of Angles, would like to particularly thank Prof. Cornelius Crowley and Dr. Corinne Alexandre-Garner of Paris Nanterre University for their support and contribution to the success of the conference.

The sea remains a symbol of what is vast, deep, mysterious and dangerous, and appears in our collective songs, myths, literature and art. Global economy and trade rely upon maritime routes and networks for keeping goods and ideas in circulation.

4 The conference was based on the premise that the sea is being reinvented everywhere as a means to resist and survive, as a strategic frontier to be redesigned, but also as home.

5 We think that a good introduction to the different and complex issues examined in this particular issue of Angles are illustrated by Derek Walcott's poem "Sea is History":

The Sea Is History

Where are your monuments, your battles, martyrs?

Where is your tribal memory? Sirs,

in that grey vault. The sea. The sea

has locked them up. The sea is History.

6 This issue has articles from authors:

1. who deal with sea as history. 
2. from authors who explore the sea as a metaphor in literature, studying the impact on language and culture of sea crossings, especially during colonial times.

3. and from authors who take up postcolonial texts dealing with environmental crises and climate change, and discuss the resulting phenomena of migration and neglect of human rights. 
In another contribution, Ahmed Mulla turns to Amitav Ghosh's novel Sea of Poppies which recounts the story Indian indentured labourers who replaced African slaves in British plantation colonies. The Indians believed that crossing of black waters (kala pani) imperiled their selves and their culture. Ahmed Mulla sustains that the process of social, cultural and linguistic creolization of the migrant Indian labourers started in the heterotopic space of the ship.

Maria-Sabina Draga Alexandru also studied texts by Amitav Ghosh, one a novel, The Hungry Tide, and the other, an essay, The Great Derangement, on climate change. If colonialism functioned on the basis of an assumption of European superiority over nonEuropean civilizations, non-European forms of knowledge now seem to prevail over western knowledge.

Ghosh's interest in climate change and the destruction caused by man can also be compared with natural catastrophes, such as the Boxing Day tsunami in 2004. In her contribution, Geetha Ganapathy-Doré studies three different narratives written by women authors that depict this cataclysmic moment in Sri Lanka. Whether it is an intensely personal trauma narrative, or a humanitarian narrative of suffering told from the outsider's point of view, or a narrative of mourning that purports to denounce the violation of human rights, the narratives she studies from and about Sri Lanka have a ripple effect on England and old hierarchies of power. They testify to the shift from the psychological to the ecological orientation of reality in the contemporary world of precarious lives.

The last contribution to this issue completes the sea-centred perspective of this issue. If we began this introduction by quoting a poem from Derek Walcott, we will conclude with Malati Mathur's article on poetry written about the Pacific. Mathur discusses Alec Dervent Hope's "Man Friday" and Christopher Brennan's "Each Day I See the Long Ships Coming Into Port." Hope's reframing of Daniel Defoe's famous novel, Robinson Crusoe, gives voice to the silenced slave, and pictures the sea as both a dividing barrier leading to exile and a welcoming bosom into the embrace of which 'to return' is 'to go home'. In Christopher Brennan's poem, on the contrary, Mathur argues that the ship carrying the narrator symbolizes prophecy, anticipation and a reaching out to other cultures. Brennan chooses to record the shaping of Australia by the migrant's experience.

Malati Mathur is a poet herself, and we would like to repeat her concluding words to end this introduction on 'Reinventing Sea':

The sea can never be possessed. It can only possess and possess absolutely.

We hope you enjoy the articles.

\section{ABSTRACTS}

This video introduces the thematic contributions on 'Reinventing the Sea'.

La vidéo présente les contributions thématiques sur « Réinventer la mer ». 


\section{INDEX}

Keywords: sea, ocean, literature, colonial history, Indian Ocean, creolization, cartography, water, climate change

Mots-clés: mer, océan, littérature, histoire coloniale, histoire antique, Océan Indien, créolisation, cartographie, eau, changement climatique

\section{AUTHORS}

\section{GEETHA GANAPATHY-DORÉ}

Guest editor of Issue 9. Research accredited Associate Professor of English at the Faculty of Law, Social and Political Sciences at Sorbonne Paris Nord University. She is attached to the Centre de Recherches Anglophones of the University of Paris Nanterre, and is associate member of IDPS at Sorbonne Paris Nord University. She is currently president of the Society for Activities and Research on the Indian World (SARI), and is the author of The Postcolonial Indian Novel in English. She has edited and co-edited several books among which figure On the Move, The Journey of Refugees in New Literatures in English and Heritage and Ruptures in Indian Literature, Culture and Cinema. Contact: geethagd[at]hotmail.com

\section{LUDMILA VOLNÁ}

Guest editor of Issue 9. Lecturer in English at Charles University, Prague. She is an associate member of ERIAC at Rouen Normandie University and of IMAGER Research Centre at Paris EstCréteil University. She is currently a Vice-President of the Society for Activities and Research on the Indian World (SARI), and the non-India membership representative at IACLALS (Delhi). She has published a large number of articles on Indian Writing in English and edited several books, among which Children of Midnight: Contemporary Indian Novel in English and Indian Birth and Western Rebirths of the Jataka Tales. Contact: ludmila.volna[at]free.fr 